\title{
Mechanisms Whereby Extracellular Adenosine 3',5'-Monophosphate Inhibits Phosphate Transport in Cultured Opossum Kidney Cells and in Rat Kidney
}

\author{
Physiological Implication
}

\author{
Gérard Friedlander, Sylvianne Couette, Christiane Coureau, and Claude Amiel \\ Department of Physiology and Institut National de la Santé et de la Recherche Médicale (INSERM) Unité 251, \\ Faculté de Médecine Xavier-Bichat, Université Paris 7, F-75018 Paris, France
}

\begin{abstract}
The mechanism of phosphaturia induced by cAMP infusion and the physiological role of extracellular cAMP in modulation of renal phosphate transport were examined. In cultured opossum kidney cells, extracellular cAMP (10-1,000 $\mu \mathrm{M})$ inhibited Na-dependent phosphate uptake in a time- and concentration-dependent manner. The effect of cAMP was reproduced by ATP, AMP, and adenosine, and was blunted by phosphodiesterase inhibitors or by dipyridamole which inhibits adenosine uptake. $\left[{ }^{3} \mathbf{H}\right]$ cAMP was degraded extracellularly into AMP and adenosine, and radioactivity accumulated in the cells as labeled adenosine and, subsequently, as adenine nucleotides including CAMP. Radioactivity accumulation was decreased by dipyridamole and by inhibitors of phosphodiesterases and ecto5'-nucleotidase, assessing the existence of stepwise hydrolysis of extracellular cAMP and intracellular processing of taken up adenosine. In vivo, dipyridamole abolished the phosphaturia induced by exogenous cAMP infusion in acutely parathyroidectomized (APTX) rats, decreased phosphate excretion in intact rats, and blunted phosphaturia induced by PTH infusion in APTX rats. These results indicate that luminal degradation of cAMP into adenosine, followed by cellular uptake of the nucleoside by tubular cells, is a key event which accounts for the phosphaturic effect of exogenous CAMP and for the part of the phosphaturic effect of PTH which is mediated by cAMP added to the tubular lumen under the influence of the hormone. ( $J$. Clin. Invest. 1992. 90:848-858.) Key words: adenosine • cyclic adenosine monophosphate $\bullet$ parathyroid hormone $\bullet$ phosphate transport • proximal tubule
\end{abstract}

\section{Introduction}

Cyclic adenosine 3',5'-monophosphate (cAMP) is currently acknowledged as a second intracellular messenger involved in signal transduction for peptidic hormones, including parathyroid hormone (PTH). Increased generation of cAMP is, together with phosphoinositide breakdown, one of the events

Part of this work was presented at the 24th Annual Meeting of the American Society of Nephrology, Baltimore, MD, 17-20 November 1991, and published in abstract form (1991. J. Am. Soc. Nephrol. 2: $620,1991)$.

Address reprint requests to Dr. Friedlander, INSERM U251, Faculté Xavier-Bichat, 16 rue Henri-Huchard, F-75018 Paris, France.

Received for publication 24 July 1991 and in revised form $12 \mathrm{De}$ cember 1992.

J. Clin. Invest.

(C) The American Society for Clinical Investigation, Inc.

$0021-9738 / 92 / 09 / 0848 / 11 \quad \$ 2.00$

Volume 90, September 1992, 848-858 which lead to PTH inhibition of sodium-Pi cotransport in renal brush border membranes, the initial step of Pi reabsorption in the renal proximal tubule (1-4). One unique feature of PTH action in the proximal tubule, but not in other renal target sites of the hormone (i.e., cortical ascending limb of Henle's loop and distal convoluted tubule), is that a substantial part of generated cAMP is transferred from the cells into the tubular lumen through the apical membranes (5). Consequently, excreted cAMP in the urine is approximately twice the filtered cAMP load (6). The difference between excreted and filtered cAMP, i.e., nephrogenous cAMP, is a reliable index of parathyroid function because it is elevated over normal values during hyperparathyroidism (6) and it is equal to zero in acutely parathyroidectomized (APTX) ${ }^{1}$ animals in which Pi excretion is abolished or decreased (7). The question of whether luminal cyclic AMP per se may influence Pi reabsorption has not been adequately addressed. However, it has been clearly established that the phosphaturic effect of PTH could be mimicked, in vivo, by systemic infusion of cAMP to APTX animals $(8,9)$ when plasma concentration of CAMP was increased to the micromolar range. Interestingly, other renal effects of PTH, such as those exerted on the loop of Henle or on the distal tubule, were not reproduced by cAMP infusion $(8,9)$. Moreover, infused cAMP did not mimick the renal effects of other peptidic hormones, such as antidiuretic hormone $(8,9)$.

These results raise the possibility that handling (i.e., metabolism and/or transport) of extracellular cAMP by proximal tubular cells was involved in the effects of the cyclic nucleotide. However, the involved mechanism has not been fully elucidated. That extracellular cAMP could enter proximal cells at their basal pole, through an organic anion transporter, has been proposed $(10,11)$. However, evidence that cAMP has a very low affinity, in the millimolar range $(11,12)$, for this transporter makes this hypothesis unlikely. Alternatively, proximal tubules in suspension were shown to metabolize extracellular cAMP and to uptake degradation products (13), especially adenosine. Adenosine uptake by tubular cells has been extensively characterized (14-17) and was reported to play a central role in the protective effect of adenine nucleotides on tubular function during and after anoxia (18).

The aim of the present study was: (a) to elucidate the mechanism by which extracellular cAMP inhibits proximal tubular Pi transport and $(b)$ to evaluate the extent to which extracellular cAMP, added to the tubular lumen under the influence of PTH, participates to the overall phosphaturic effect of the hormone.

1. Abbreviations used in this paper: APTX, acutely parathyroidectomized; bPTH, bovine PTH; dBcAMP, dibutyryl-cAMP; MGP, $\alpha$ methyl-D-glucopyranoside; OK, opossum kidney; PAH, $p$-aminohippuric acid. 


\section{Methods}

This study combined in vitro experiments, conducted in cultured renal cells, and in vivo experiments conducted in rats with various parathyroid status.

Materials. Ethanolamine, insulin, transferrin, hydrocortisone, triiodothyronine, $\alpha$-methyl-D-glucopyranoside (MGP), L-alanine, Daspartate, 1-34 fragment of bovine PTH (bPTH 1-34), Na selenite, dipyridamole, probenecid, $p$-aminohippuric acid (PAH), amiloride, adenine nucleotides, $\alpha, \beta$-methyleneadenosine 5 '-diphosphate, bovine serum albumin were purchased from Sigma Chemical Co. (St. Louis, MO). RO 20-1724 was a kind gift from Hoffmann-La Roche Laboratories (Basel, Switzerland). Tracers were from the following sources: $\mathrm{K}_{2} \mathrm{H}^{32} \mathrm{PO}_{4}$ and $\left[\right.$ methoxy $-{ }^{3} \mathrm{H}$ ] inulin from New England Nuclear (Boston, MA), methyl- $\alpha$-D- $\left[\mathrm{U}-{ }^{14} \mathrm{C}\right]$ glucopyranoside $\left(\left[{ }^{14} \mathrm{C}\right] \mathrm{MGP}\right),{ }^{32} \mathrm{P}$ neutral sodium phosphate, $\left[2,5^{\prime}, 8-{ }^{3} \mathrm{H}\right]$ adenosine, $\left[2,8-{ }^{3} \mathrm{H}\right] \mathrm{cAMP}, \mathrm{D}-$ $\left[{ }^{3} \mathrm{H}\right]$ aspartate, and $\mathrm{L}-\left[2,3-{ }^{3} \mathrm{H}\right]$ alanine from Amersham International (Amersham, UK). Polyethyleneimine cellulose sheets were from E. Merck (Darmstadt, FRG). Culture media and reagents were from Gibco-BRL (Cergy-Pontoise, France). Plasticware was from Costar (Cambridge, MA). All other reagents were of analytical grade.

Cell culture. Opossum kidney (OK) cells (passages 80-100) were grown to confluence in 6- or 24-well trays in a medium consisting of a 1:1 ( vol/vol) mixture of Ham's F-12 and Dulbecco's modified Eagle's medium containing $15 \mathrm{mM}$ Hepes, $21.5 \mathrm{mM} \mathrm{HCO}_{3}, 1 \mathrm{mM} \mathrm{Na}$ pyruvate, $4 \mathrm{mM}$ L-glutamine, $50 \mathrm{U} / \mathrm{ml}$ penicillin, $50 \mu \mathrm{g} / \mathrm{ml}$ streptomycin, $50 \mathrm{nM}$ Na selenite, $5 \mu \mathrm{g} / \mathrm{ml}$ insulin, $5 \mu \mathrm{g} / \mathrm{ml}$ transferrin, $5 \mathrm{nM}$ triiodothyronine, $50 \mathrm{nM}$ hydrocortisone, and $2.5 \%$ fetal calf serum. Medium was changed on alternate days. Monolayers of $\mathrm{OK}$ cells reached confluence after $4 \mathrm{~d}$, and they were used for experiments 2 or $3 \mathrm{~d}$ after confluence was achieved. Cells were subcultured weekly by trypsinization. The splitting ratio was 1:5.

On the day before experiments, culture medium was changed to hormone-free and serum-free medium, and, on the day of experiment, preincubations with hormones or nucleotides were usually performed in the same medium to which hormones or drugs were added as concentrated aliquots.

Uptake studies. Uptakes of $\mathrm{Pi}, \mathrm{MGP}$, alanine, aspartate, and adenosine were performed as previously described with minor modifications $(19,20)$. Briefly, uptakes were performed at $37^{\circ} \mathrm{C}$ in a buffered solution with the following composition (mmol/liter): $137 \mathrm{NaCl}, 5.4 \mathrm{KCl}$, $1 \mathrm{CaCl}_{2}, 1.2 \mathrm{MgSO}_{4}, 15 \mathrm{Hepes}$ ( $\mathrm{pH} 7.4$ ). The sodium-free solution was made isoosmotic by replacing sodium chloride with $N$-methyl-D-glucamine. After removal of culture medium, cells were washed with $1 \mathrm{ml}$ per well of the uptake solution, and were incubated for various periods of time in the presence of one of the following: $\mathrm{K}_{2} \mathrm{H}^{32} \mathrm{PO}_{4}(0.5 \mu \mathrm{Ci} /$ $\mathrm{ml}),\left[{ }^{14} \mathrm{C}\right] \mathrm{MGP}(0.5 \mu \mathrm{Ci} / \mathrm{ml}), \mathrm{L}-\left[{ }^{3} \mathrm{H}\right]$ alanine $(1 \mu \mathrm{Ci} / \mathrm{ml}), \mathrm{D}-\left[{ }^{3} \mathrm{H}\right]-$ aspartate $(1 \mu \mathrm{Ci} / \mathrm{ml})$, or $\left[{ }^{3} \mathrm{H}\right]$ adenosine $(1 \mu \mathrm{Ci} / \mathrm{ml})$ and appropriate concentrations of $\mathrm{KH}_{2} \mathrm{PO}_{4}$, MGP, L-alanine, D-aspartate, or adenosine. All these steps were performed at $37^{\circ} \mathrm{C}$. At the end of incubation, the uptake was stopped by washing the cells three times with $1 \mathrm{ml} /$ well of ice-cold solution ( $137 \mathrm{mM} \mathrm{NaCl} / 15 \mathrm{mM}$ Hepes, $\mathrm{pH} 7.4$ ). Cells were then solubilized in $0.5 \%$ Triton X-100 (250 $\mu$ l per well) and aliquots were counted by liquid scintillation.

Uptake of $\left[{ }^{3} \mathrm{H}\right]$ cAMP was performed in Hank's balanced salt solution supplemented with $2 \mathrm{mM}$ glutamine and $15 \mathrm{mM}$ Hepes, $\mathrm{pH}$ 7.4. After removal of culture medium, cells were washed with $1 \mathrm{ml}$ per well of the uptake solution, and were incubated for various periods of time in the presence of $\left[{ }^{3} \mathrm{H}\right] \mathrm{cAMP}(1 \mu \mathrm{Ci} / \mathrm{ml})$ and appropriate concentrations of cAMP. At the end of incubation, cells were processed as described above for other uptakes.

Metabolism of labeled nucleotides. Procedures were adapted from Boumendil-Podevin and Podevin (13). For these experiments, cells were grown in six-well trays. Incubations with labeled cAMP were performed as described above for uptake studies. At the end of incubation, a 200- $\mu$ l aliquot of medium from each well was transferred to a glass tube containing $3 \mathrm{ml}$ of ice-cold $90 \%$ isopropyl alcohol and the remaining medium was aspirated. $1.5 \mathrm{ml}$ of ice-cold $90 \%$ isopropyl alcohol were then added to each well. Cells were sonicated in a water bath during $2 \mathrm{~min}$, the extracts were centrifuged to remove proteins, and the supernatants were transferred to glass tubes. This operation was repeated once. Supernatants were pooled, extracts were evaporated to dryness under vacuum, and the residues were dissolved in $100 \mu \mathrm{l}$ of $90 \%$ isopropyl alcohol. Aliquots of the isopropanol solutions with appropriate markers were spotted on polyethyleneimine-cellulose sheets with wedged-tip division. The plates were developed for $6 \mathrm{~h}$ using a solvent system of $95 \%$ ethanol $/ 5 \mathrm{M}$ ammonium acetate $(5: 2, \mathrm{vol} / \mathrm{vol})$. After drying, spots were located under ultraviolet light. Average $R_{\mathrm{F}}$ values for standards were as follows: uric acid, 0.00; ATP, 0.05; ADP, 0.08; AMP, 0.14; cAMP, 0.40; hypoxanthine-inosine, 0.60; adenosine, 0.68 . The reference spots were cut out and removed from the plastic backing by sonication in $2 \mathrm{ml}$ of $0.1 \mathrm{~N} \mathrm{NaOH}$, and 1-ml aliquots were taken for radioactivity estimation. Recovery of ${ }^{3} \mathrm{H}$ from the plates was $>80 \%$.

In vivo studies. Experiments were performed on 24 male SpragueDawley rats, of average weight $198 \pm 8 \mathrm{~g}$. Feeding, anesthesia, infusion (saline, $\left[{ }^{3} \mathrm{H}\right]$ inulin, ${ }^{32} \mathrm{P}$ ), surgical preparation and clearances were as previously described (9). Seven groups of rats were studied. In group I, three acutely APTX rats were infused with cAMP, $4 \mathrm{nmol} / \mathrm{min}$ per 100 $\mathrm{g}$ of body wt after a priming dose of $1 \mathrm{nmol} / 100 \mathrm{~g}$ of body $\mathrm{wt}$, after a control period. Group II consisted in three APTX rats, infused with cAMP as in group I; in addition, dipyridamole, $25 \mu \mathrm{g} / \mathrm{min}$ per $100 \mathrm{~g}$ of body wt, was infused throughout the experiment. Groups III and IV consisted in APTX rats ( $n=3$ in each group) infused with dibutyrylcAMP ( $\mathrm{dBcAMP}), 40 \mathrm{nmol} / \mathrm{min}$ per $100 \mathrm{~g}$ of body wt after a priming dose of $5 \mathrm{nmol} / 100 \mathrm{~g}$ of body wt, after a control period. Dipyridamole was infused in group IV as in group II. In groups V $(n=5)$ and VI ( $n$ $=3$ ), APTX rats were infused throughout the experiment with bPTH $1-34,1 \mathrm{U} / \mathrm{h}$ per $100 \mathrm{~g}$ of body wt. Dipyridamole was infused in group VI at the same rate as in groups II and IV, after a control period without the drug. Finally, group VII consisted of four intact rats receiving a dipyridamole infusion at the same rate as in groups II, IV, and VI, after a control period without the drug.

Presentation of data. Uptakes of Pi, MGP, alanine, aspartate, adenosine, and cAMP were expressed as picomoles or nanomoles per milligram of protein (21). Na-dependent uptakes were calculated by subtracting uptake values measured in the presence of $N$-methyl-D-glucamine from those measured in the presence of $\mathrm{Na}$. Results of in vivo experiments were expressed in terms of fractional Pi excretion in urine. Results were presented as mean $\pm \mathrm{SE}$ of three to five different experiments $(n)$ in which duplicates were obtained. One-way or two-way analyses of variance were performed and, when allowed by the $F$ value, results were compared by the modified $t$ test (22).

\section{Results}

Extracellular cAMP uptake and metabolism. Incubation of OK cells with $\left[{ }^{3} \mathrm{H}\right]$ cAMP resulted in cellular accumulation of radioactivity which increased linearly with time up to $3 \mathrm{~h}$ (Fig. $1 A$ ). Radioactivity accumulation was decreased in a concentration-dependent manner by RO 20-1724 and probenecid, two documented phosphodiesterase inhibitors (23-25) (Fig. 1 $B)$, raising the possibility that extracellular cAMP was degraded into 5'-AMP before uptake. Cell-associated radioactivity, which accumulated mainly through a Na-independent pathway (Fig. $2 A$ ), was also decreased by $\alpha, \beta$-methyleneadenosine 5'-diphosphate, a 5'-nucleotidase inhibitor (reviewed in reference 26), and by dipyridamole, which blocks adenosine uptake (Fig. $2 A$ ), suggesting that tritiated material was uptaken mainly as adenosine. This possibility was reinforced by the 

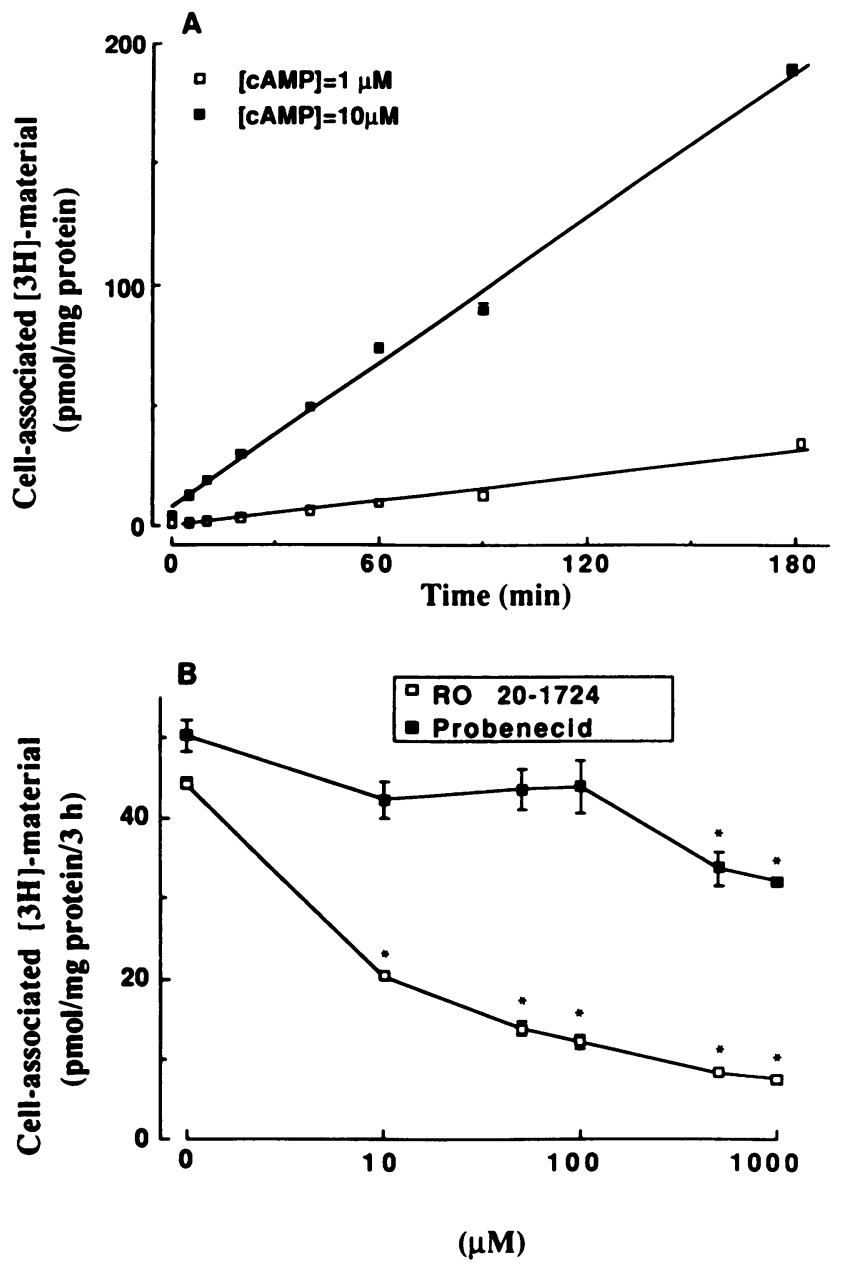

Figure 1. Uptake of radioactivity by $\mathrm{OK}$ cells incubated with $\left[{ }^{3} \mathrm{H}\right]-$ cAMP: time course and effect of RO 20-1724 and probenecid. $(A)$ OK cells were incubated during various periods of time in the presence of $\left[{ }^{3} \mathrm{H}\right] \mathrm{cAMP}(1 \mu \mathrm{Ci} / \mathrm{ml})$ and unlabeled cAMP either at $1 \mu \mathrm{M}$ $(\square)$ or at $10 \mu \mathrm{M}(\square)$. (B) OK cells were incubated during $3 \mathrm{~h}$ with $\left[{ }^{3} \mathrm{H}\right] \mathrm{cAMP}(1 \mu \mathrm{Ci} / \mathrm{ml}, 1 \mu \mathrm{M})$ and increasing concentrations of RO 20-1724 ( $\square$ ) or probenecid ( $\square$ ). Results are expressed as means \pm SE of three different $(n=3)$ experiments in which duplicates were obtained. *Significantly different from homologous control value, $P$ $<0.01$.

fact that addition of unlabeled adenosine, AMP, or ATP to the incubation medium depressed radioactivity accumulation. In contrast, hypoxanthine, xanthine, and inosine, which do not lead to adenosine formation, were less or not effective (Fig. 2 $B)$. Cellular accumulation of tritiated material was inhibited in a concentration-dependent manner by cAMP and, to a much lesser extent, by dBcAMP ( Table I). In contrast, cGMP had no effect on radioactivity accumulation while PAH exerted only a modest inhibition at the higher concentration used ( $1 \mathrm{mM})$ ( Table I). Kinetic analysis of ${ }^{3} \mathrm{H}$-labeled material uptake revealed that two transport systems were involved: the first one had a low capacity $\left(V_{\max }=123 \mathrm{pmol} / \mathrm{mg}\right.$ protein per $\left.1 \mathrm{~h}\right)$ and a high affinity $\left(K_{\mathrm{m} 1}=11.5 \mu \mathrm{M}\right)$; the second one was characterized by a high capacity $\left(V_{\max }=19.8 \mathrm{nmol} / \mathrm{mg}\right.$ protein per $\left.1 \mathrm{~h}\right)$ and a low affinity $\left(K_{\mathrm{m} 2}=3.6 \mathrm{mM}\right)$ (Fig. 3$)$.

When OK cells were incubated in the presence of $\left[{ }^{3} \mathrm{H}\right]-$
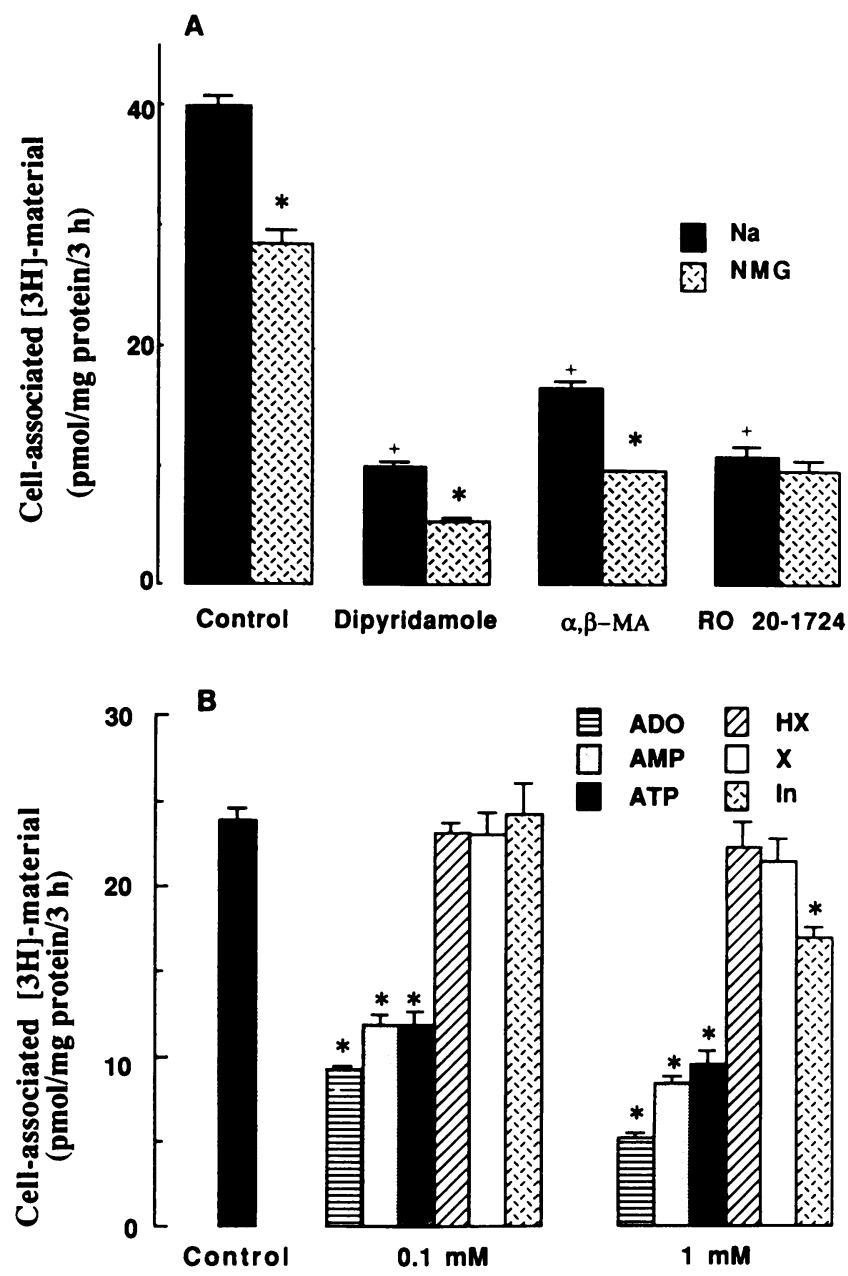

Figure 2. Uptake of radioactivity by $\mathrm{OK}$ cells incubated with $\left[{ }^{3} \mathrm{H}\right]-$ cAMP: effect of metabolic or transport inhibitors and of nucleosites and nucleotides. $(A)$ OK cells were incubated during $3 \mathrm{~h}$ with $\left[{ }^{3} \mathrm{H}\right]-$ cAMP $(1 \mu \mathrm{Ci} / \mathrm{ml}, 1 \mu \mathrm{M})$ and dipyridamole $(20 \mu \mathrm{M}), \alpha, \beta$-methyleneadenosine-5'-diphosphate $(\alpha, \beta-M A, 10 \mu \mathrm{M})$, or RO 20-1724 (50 $\mu \mathrm{M}$ ), in isoosmolar solution containing either $\mathrm{Na}$ ( solid columns) or $N$-methyl-D-glucamine ( $N M G$, dotted columns) ${ }^{+}$Significantly different from homologous control value, $P<0.01$. *Significantly different from homologous value with $\mathrm{Na}, P<0.01$. ( $B) \mathrm{OK}$ cells were incubated during $3 \mathrm{~h}$ with $\left[{ }^{3} \mathrm{H}\right] \mathrm{cAMP}(1 \mu \mathrm{Ci} / \mathrm{ml}, 1 \mu \mathrm{M})$ and adenosine $(A D O)$, AMP, ATP, hypoxanthine $(H X)$, xanthine $(X)$, or inosine $(I n)$, each of them at $0.1 \mathrm{mM}$ or $1 \mathrm{mM}$. *Significantly different from homologous control value, $P<0.01$. Results are expressed as means \pm SE of four different $(n=4)$ experiments in which duplicates were obtained.

cAMP, accumulated radioactivity was predominantly under the form of adenosine which accumulated in a time-dependent manner (Fig. 4). Both dipyridamole and RO 20-1724 inhibited adenosine accumulation. Adenosine accumulation preceeded that of AMP, ATP, and cAMP which accumulated in the cells to a lesser extent (Fig. 4). Again, accumulation of these nucleotides was dramatically inhibited by dipyridamole and RO 20-1724. In the medium, part of $\left[{ }^{3} \mathrm{H}\right]$ cAMP had been converted to 5'-AMP and, to a lesser extent, to adenosine (Fig. 5). As expected, RO 20-1724 blunted conversion of cAMP into AMP and adenosine. 
Table I. Inhibitory Effect of Unlabeled Cyclic Nucleotides and PAH on Radioactivity Accumulation in OK Cells Incubated with $\left[{ }^{3} H\right] c A M P$

\begin{tabular}{ccrrr}
\hline & \multicolumn{4}{c}{ Magnitude of inhibition } \\
\cline { 2 - 5 } Concentration & \multicolumn{1}{c}{ cAMP } & \multicolumn{1}{c}{ dBcAMP } & cGMP & PAH \\
\hline$\mu M$ & & & & \\
& & & & \\
10 & $35.3 \pm 4.3$ & $8.2 \pm 9.2$ & $1.5 \pm 5.9$ & $4.4 \pm 3.6$ \\
100 & $43.9 \pm 5.2$ & $26.0 \pm 6.4$ & $4.7 \pm 6.6$ & $13.0 \pm 9.3$ \\
1000 & $55.0 \pm 2.1$ & $43.2 \pm 2.7$ & $10.0 \pm 9.2$ & $27.1 \pm 4.9$
\end{tabular}

OK cells were incubated during $3 \mathrm{~h}$ with $\left[{ }^{3} \mathrm{H}\right] \mathrm{cAMP}(1 \mu \mathrm{Ci} / \mathrm{ml}, 1 \mu \mathrm{M})$ in the absence or presence of increasing concentrations of unlabeled cAMP, dBcAMP, cGMP, or PAH. The control value, in the absence of unlabeled nucleotides or PAH was $19,600 \pm 750 \mathrm{cpm} / 3 \mathrm{~h}$ per $\mathrm{mg}$ of protein. For each concentration, the inhibition by $\mathrm{dBcAMP}$, cGMP, or PAH was significantly of lower magnitude than that induced by cAMP $(P<0.01)$. Results are expressed as means \pm SE of three different $(n=3)$ experiments in which duplicates were obtained.

Adenosine uptake. Adenosine uptake by OK cells increased linearly with time up to 20 min of incubation (Fig. 6). Uptake was, to a large extent, $\mathrm{Na}$-independent and was blocked by 20 $\mu \mathrm{M}$ dipyridamole. Adenosine uptake was not affected by $1 \mathrm{mM}$ probenecid, $100 \mu \mathrm{M}$ RO 20-1724, and $1 \mathrm{mM}$ unlabeled cAMP $(1.7 \pm 0.3,1.5 \pm 0.2,1.4 \pm 0.4,1.7 \pm 0.2 \mathrm{nmol} / \mathrm{mg}$ protein per 10 $\mathrm{min}$ in control conditions and in the presence of probenecid, RO 20-1724, or cAMP, respectively; not significant). Analysis of intracellular labeled metabolites after adenosine uptake revealed a pattern similar to that observed when cells were incubated with tritiated cAMP (Fig. 4): accumulated adenosine was converted to ATP and, to a lesser extent, to cAMP.
Analysis of the kinetic parameters of $\mathrm{Na}$-independent adenosine uptake was consistent with the existence of one transport system with the following kinetic parameters: $V_{\max }=4.1 \mathrm{nmol} /$ mg protein per $10 \mathrm{~min} ; K_{\mathrm{m}}=18 \mu \mathrm{M}$ (Fig. 7).

Effect of extracellular cAMP on $\mathrm{Na}$-Pi cotransport in $\mathrm{OK}$ cells. Extracellular cAMP decreased Na-dependent Pi uptake in a concentration- and time-dependent manner (Fig. 8). In subsequent experiments, OK cells were incubated with cAMP or other nucleotides during $3 \mathrm{~h}$.

In order to evaluate whether metabolism of extracellular cAMP influenced its action on Pi uptake, we first studied the effect of the phosphodiesterase inhibitor RO 20-1724. As shown in Table II, RO 20-1724 inhibited concentration-dependently Pi uptake, most likely as a result of increased intracellular cAMP accumulation $(27,28)$. However, in the presence of RO 20-1724, the inhibitory effect of exogenous cAMP was blunted ( Table II). Similar results were obtained with probenecid (Fig. $9 \mathrm{~A}$ ). At $1 \mathrm{mM}$, probenecid inhibited Pi uptake and blunted to a large extent further inhibition of Pi uptake by extracellular cAMP. Dipyridamole, at $20 \mu \mathrm{M}$, suppressed the inhibition of Pi uptake induced by up to $100 \mu \mathrm{M}$ cAMP (Fig. 9 $A)$. The results obtained with dibutyryl-cAMP, a permeant, phosphodiesterase-resistant analogue of cAMP, were strikingly different (Fig. $9 B$ ). The concentration-dependent inhibition of $\mathrm{Pi}$ uptake elicited by dibutyryl-cAMP persisted to a similar extent in the presence of probenecid and dipyridamole, suggesting that, at variance with cAMP, dibutyryl-cAMP entered the cells in intact form. Because PAH was reported, in another system, to compete with cyclic nucleotides for entry in proximal tubular cells (12), we evaluated the effect of increasing concentrations of PAH on inhibition by $1 \mathrm{mM}$ cAMP of Nadependent Pi uptake. At the maximal PAH concentration tested, $1 \mathrm{mM}$, this drug had no intrinsic effect on Pi uptake $(5.8 \pm 0.4$ vs. $5.4 \pm 0.6 \mathrm{nmol} / \mathrm{mg}$ protein per $5 \mathrm{~min}$ with or with-
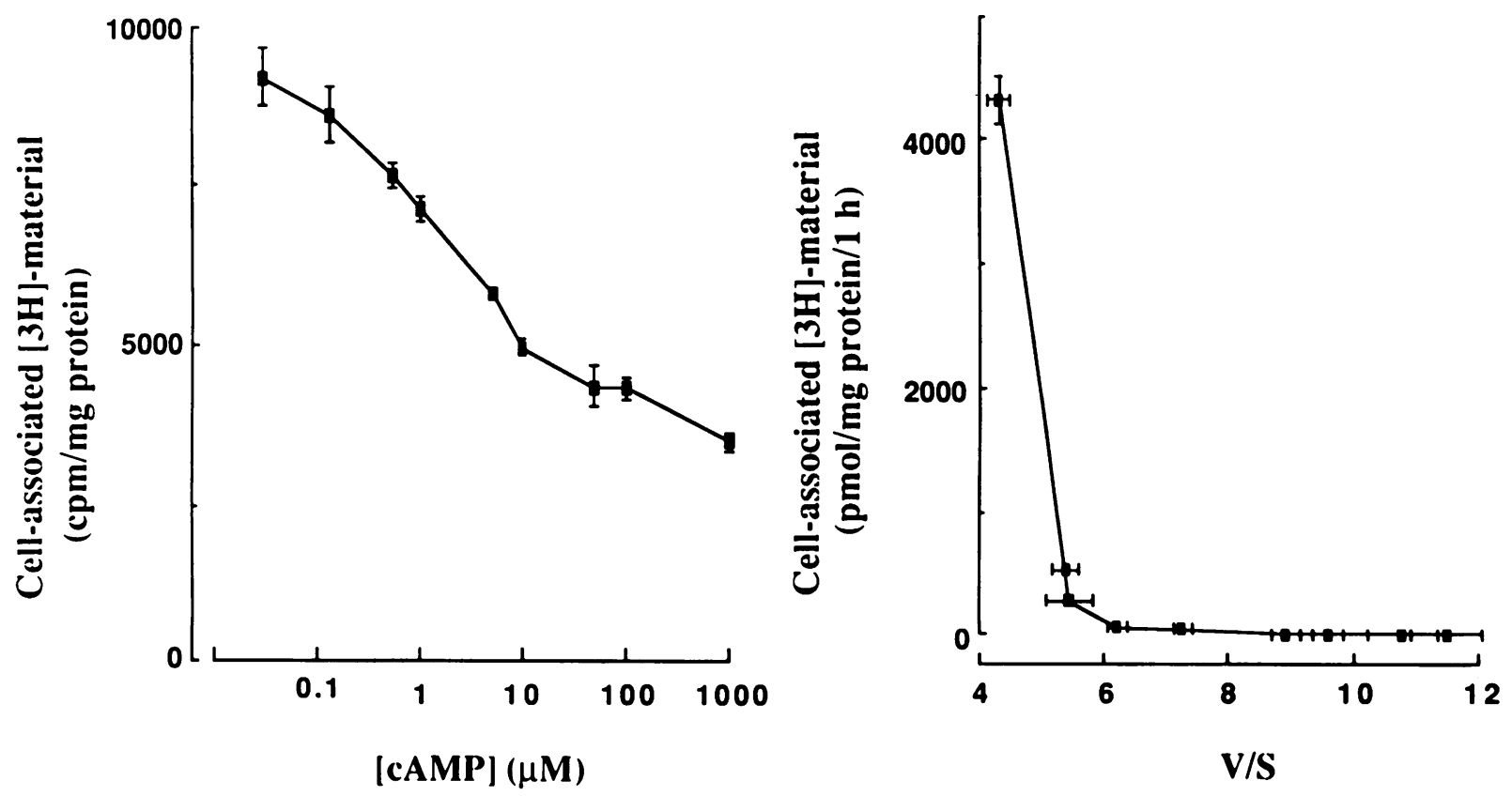

Figure 3. Kinetic analysis of uptake of radioactivity by OK cells incubated with $\left[{ }^{3} \mathrm{H}\right] \mathrm{cAMP}$. Left panel: OK cells were incubated during $1 \mathrm{~h}$ with $\left[{ }^{3} \mathrm{H}\right]$ cAMP $(1 \mu \mathrm{Ci} / \mathrm{ml})$ and various concentrations of unlabeled cAMP. Right panel: Eadie-Hofstee plot of data. Results are expressed as means \pm SE of three different $(n=3)$ experiments in which duplicates were obtained. 

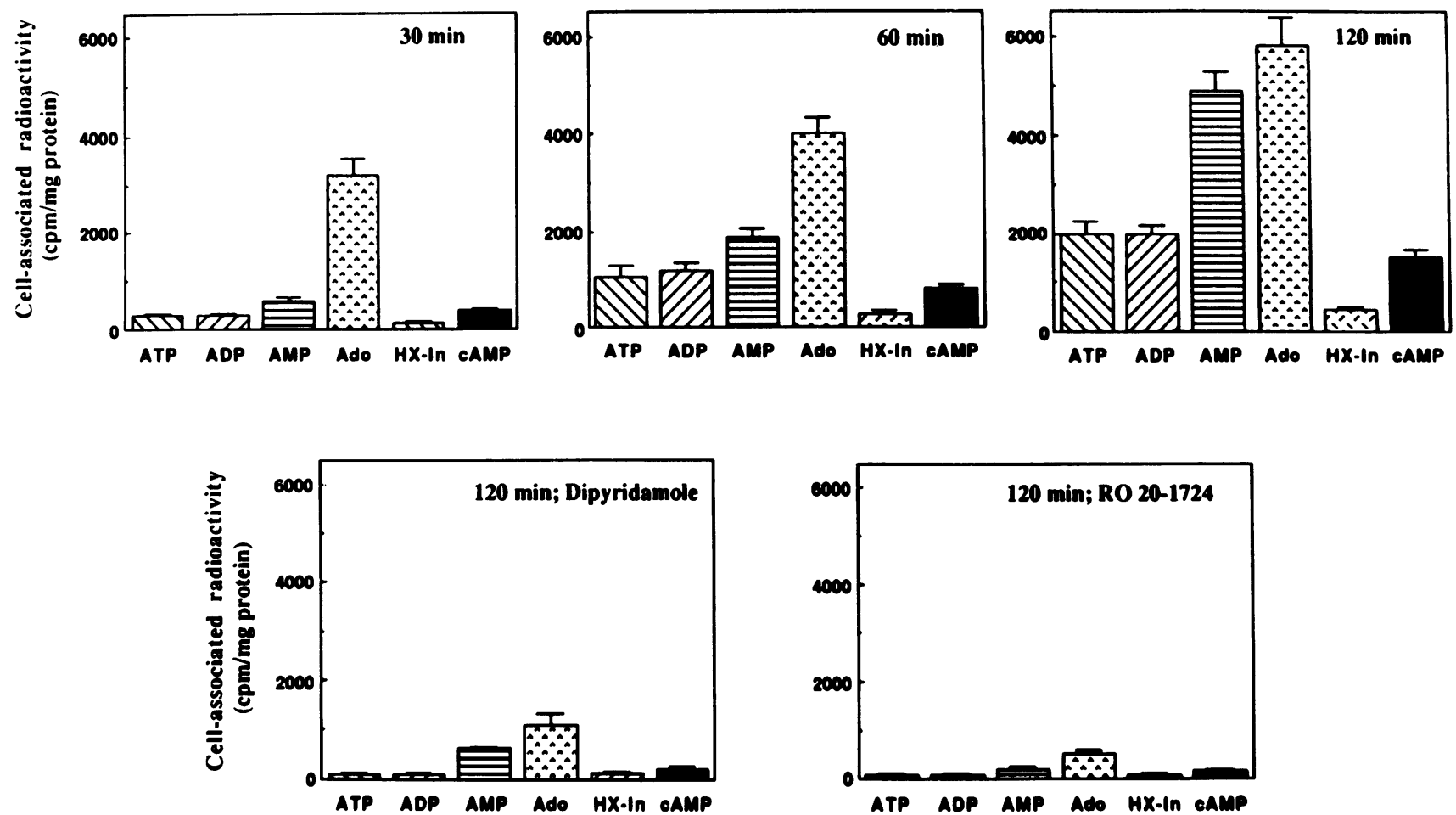

Figure 4. Identification of labeled metabolites accumulated in OK cells incubated with $\left[{ }^{3} \mathrm{H}\right] \mathrm{cAMP}$. OK cells were incubated during 30,60 , or 120 min with $\left[{ }^{3} \mathrm{H}\right]$ cAMP $(1 \mu \mathrm{Ci} / \mathrm{ml})$ in the absence or in the presence of dipyridamole $(20 \mu \mathrm{M})$ or RO 20-1724 (100 $\left.\mu \mathrm{M}\right)$. Labeled metabolites in the cells were separated as described in Methods. Results are expressed as means \pm SE of three different $(n=3)$ experiments in which duplicates were obtained. Abbreviations are as given in Fig. 2.
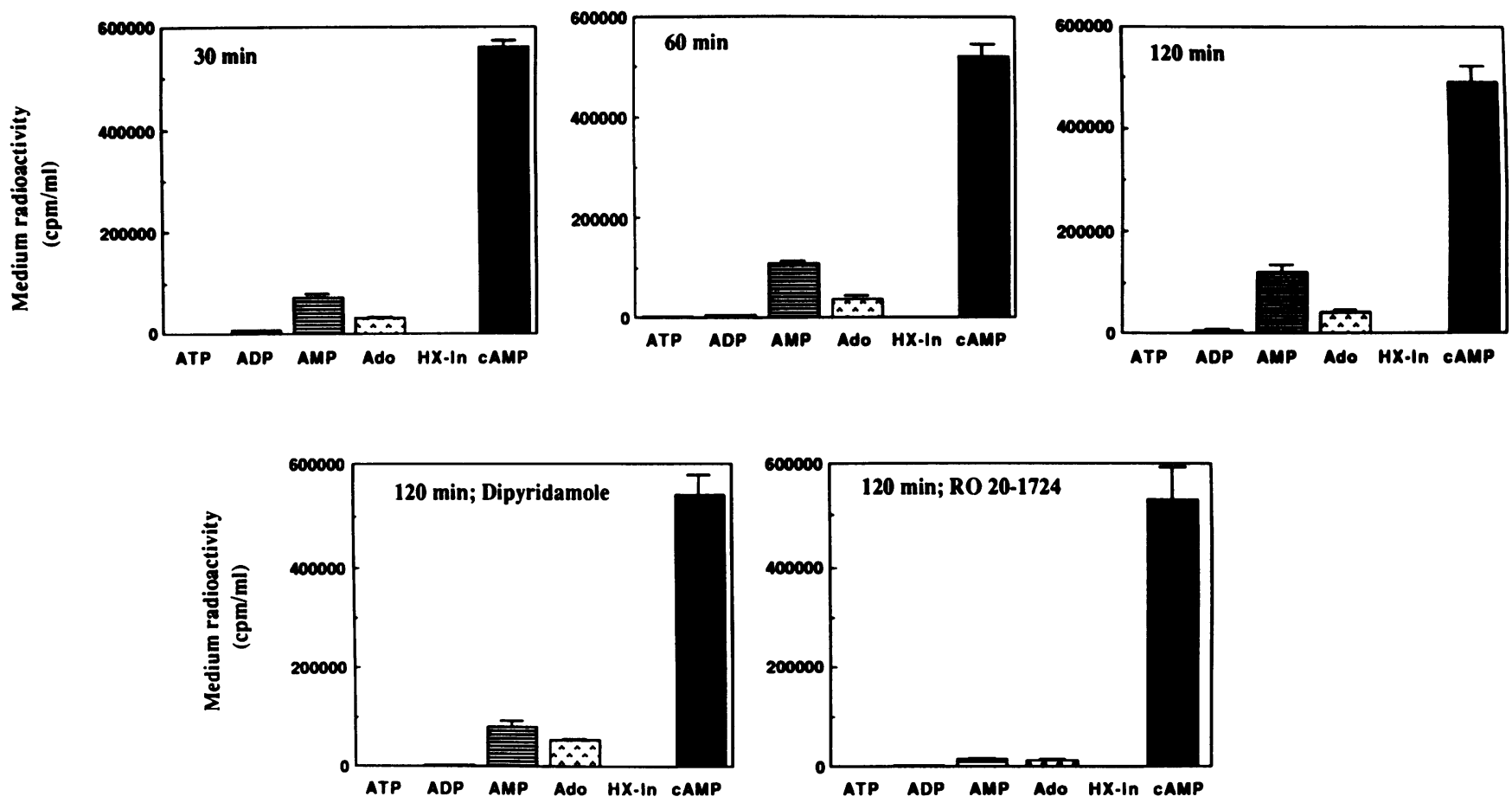

Figure 5. Identification of labeled metabolites accumulated extracellularly during incubation of OK cells with $\left[{ }^{3} \mathrm{H}\right] \mathrm{cAMP}$. OK cells were incubated during 30,60 , or $120 \mathrm{~min}$ with $\left[{ }^{3} \mathrm{H}\right] \mathrm{cAMP}(1 \mu \mathrm{Ci} / \mathrm{ml})$ in the absence or in the presence of dipyridamole $(20 \mu \mathrm{M})$ or RO $20-1724(100$ $\mu \mathrm{M})$. Labeled metabolites in the extracellular medium were separated as described in Methods. Results are expressed as means \pm SE of three different $(n=3)$ experiments in which duplicates were obtained. Abbreviations are as given in Fig. 2. 


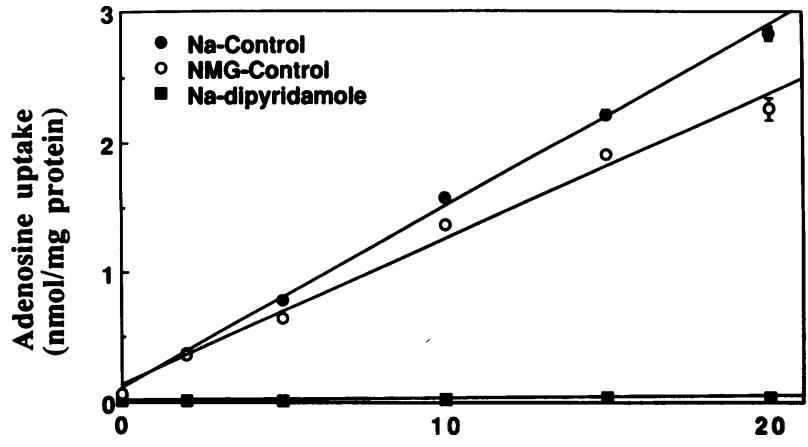

Figure 6. Time course of adenosine uptake by OK cells. OK cells were incubated with $\left[{ }^{3} \mathrm{H}\right]$ adenosine $(1 \mu \mathrm{Ci} / \mathrm{ml}, 10 \mu \mathrm{M})$ during various periods of time in isoosmotic solutions containing either $\mathrm{Na}(\bullet)$ or $N$-methyl-D-glucamine $(N M G, \circ)$. Dipyridamole $(20 \mu \mathrm{M}, \bullet)$ was added to Na-containing solution. Results are expressed as means \pm SE of three different $(n=3)$ experiments in which duplicates were obtained.

out PAH, respectively, $n=3$, NS). PAH did not affect the inhibition by cAMP of Pi uptake: cAMP decreased Pi uptake to $2.5 \pm 0.3$ and $2.8 \pm 0.5 \mathrm{nmol} / \mathrm{mg}$ protein per $5 \mathrm{~min}$ in absence or presence of PAH, respectively ( $n=3, \mathrm{NS}$ ).

To test further the possibility that the effect of cAMP was exerted, at least in part, by a metabolite of the cyclic nucleotide, we examined the effect of parent compounds on $\mathrm{Na}$-dependent Pi uptake. Incubation of OK cells during $3 \mathrm{~h}$ with adenosine, AMP, or ATP, each of them at $1 \mathrm{mM}$, resulted in an inhibition of Pi uptake (Fig. 10, top). Hypoxanthine, xanthine, and inosine were without effect. In fact, adenosine-induced inhibition of Pi uptake was already maximal at $10 \mu \mathrm{M}$ adenosine (Fig. 10, bottom). The effect of adenosine was abolished in the presence of $20 \mu \mathrm{M}$ dipyridamole.

Finally, we evaluated the effect of RO 20-1724, dipyridamole, and probenecid on PTH-induced inhibition of Pi uptake. As previously reported by others $(27,28)$, PTH inhibited Na-dependent Pi uptake in a concentration-dependent man-
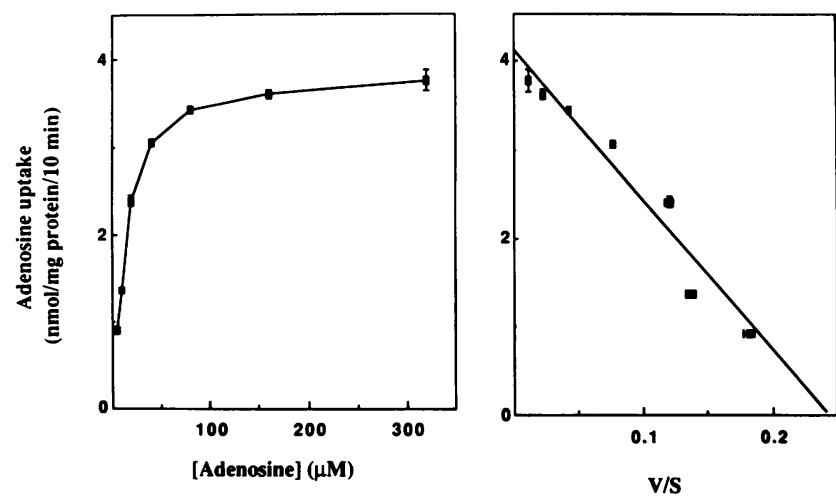

Figure 7. Kinetic analysis of $\mathrm{Na}$-independent adenosine uptake by OK cells. Left panel: OK cells were incubated during $10 \mathrm{~min}$ with $\left[{ }^{3} \mathrm{H}\right]$ adenosine $(1 \mu \mathrm{Ci} / \mathrm{ml})$ and various concentrations of unlabeled adenosine in solution made isoosmotic with $N$-methyl-D-glucámine. Right panel: Eadie-Hofstee plot of data. Results are expressed as means \pm SE of three different $(n=3)$ experiments in which duplicates were obtained.

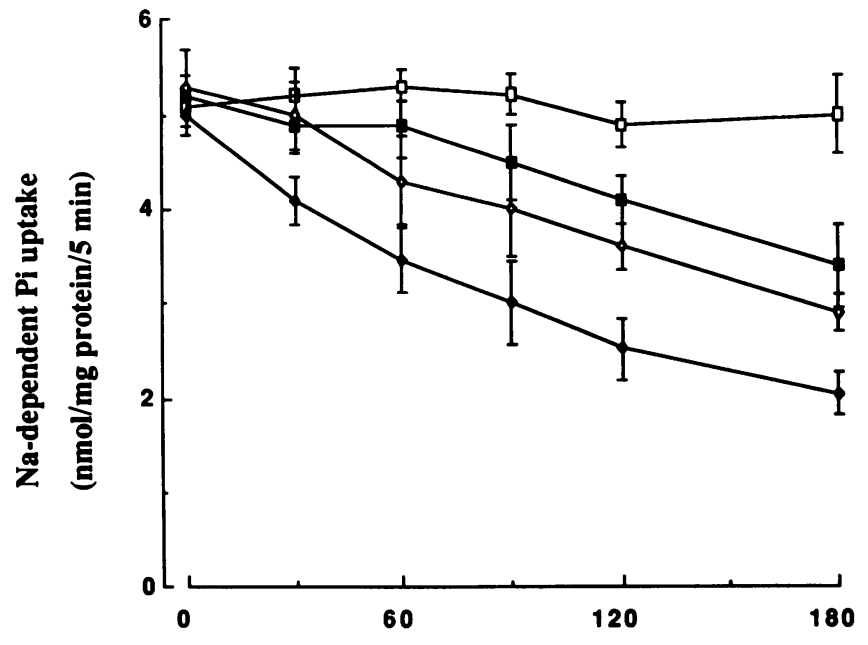

Incubation time (min)

Figure 8. Time course of the effect of extracellular cAMP on Na-dependent $\mathrm{Pi}$ uptake by $\mathrm{OK}$ cells. OK cells were incubated during various periods of time (ם) without or with (घ) 10 , (O) 100 , or $(\bullet)$ $1000 \mu \mathrm{M}$ cAMP before Pi uptake $(0.5 \mu \mathrm{Ci} / \mathrm{ml}, 0.1 \mathrm{mM}, 5 \mathrm{~min})$. Results are expressed as means \pm SE of three different $(n=3)$ experiments in which duplicates were obtained.

ner (Table III). RO 20-1724, dipyridamole, or probenecid did not influence the inhibitory effect of PTH.

Effect of extracellular CAMP on Na-Ala, Na-aspartate and $\mathrm{Na}-\mathrm{MGP}$ cotransport, and on Na-H exchange in $\mathrm{OK}$ cells. To evaluate whether extracellular cAMP affected selectively $\mathrm{Na}-\mathrm{Pi}$ cotransport, we studied the effect of cAMP and of activators of the adenylate cyclase-cAMP system on other Na-coupled uptakes. As shown in Table IV, neither extracellular cAMP nor agents and hormones known to increase intracellular cAMP

Table II. Effect of Extracellular cAMP and RO 20-1724, Alone or in Combination, on Na-dependent Pi Uptake by OK Cells

\begin{tabular}{rcccc}
\hline & \multicolumn{5}{c}{ [RO 20-1724] } \\
\cline { 2 - 5 } [CAMP] & 0 & \multicolumn{4}{c}{$\mu M$} \\
\hline$\mu M$ & \multicolumn{4}{c}{ nmol/mg protein per 5 min } \\
& \multicolumn{4}{c}{50} \\
0 & $5.6 \pm 0.19$ & $3.9 \pm 0.13$ & $3.6 \pm 0.15$ & $2.8 \pm 0.12$ \\
10 & $4.9 \pm 0.12$ & $3.6 \pm 0.13$ & $3.4 \pm 0.17$ & $2.8 \pm 0.14$ \\
& $(-12.5 \pm 2.1 \%)$ & $(-6.7 \pm 3.3 \%)$ & $(-6.7 \pm 4.7 \%)$ & $(0.0 \pm 5.0 \%)$ \\
100 & $3.8 \pm 0.06$ & $2.8 \pm 0.06$ & $2.8 \pm 0.16$ & $2.2 \pm 0.10$ \\
& $(-32.8 \pm 1.0 \%)$ & $(-29.5 \pm 1.5 \%)$ & $(-22.2 \pm 4.4 \%)$ & $-20.1 \pm 3.6 \%)$ \\
1,000 & $2.7 \pm 0.06$ & $2.0 \pm 0.04$ & $2.0 \pm 0.14$ & $1.7 \pm 0.05$ \\
& $(-51.3 \pm 1.1 \%)$ & $(-48.2 \pm 1.0 \%)$ & $(-44.4 \pm 3.9 \%)$ & $(-31.3 \pm 1.6 \%)$
\end{tabular}

OK cells were incubated during $3 \mathrm{~h}$ in the absence or presence of cAMP and RO 20-1724, alone or in combination, before Pi uptake $(0.1 \mathrm{mM})$. Numbers in parentheses refer to magnitude of inhibition as compared to homologous value without cAMP. Results represent means \pm SE of three different experiments $(n=3)$ in which duplicates were obtained. At any concentration of RO 20-1724, the inhibition by cAMP was significantly of lower magnitude than in the absence of RO 20-1724 $(P<0.05)$. 
A
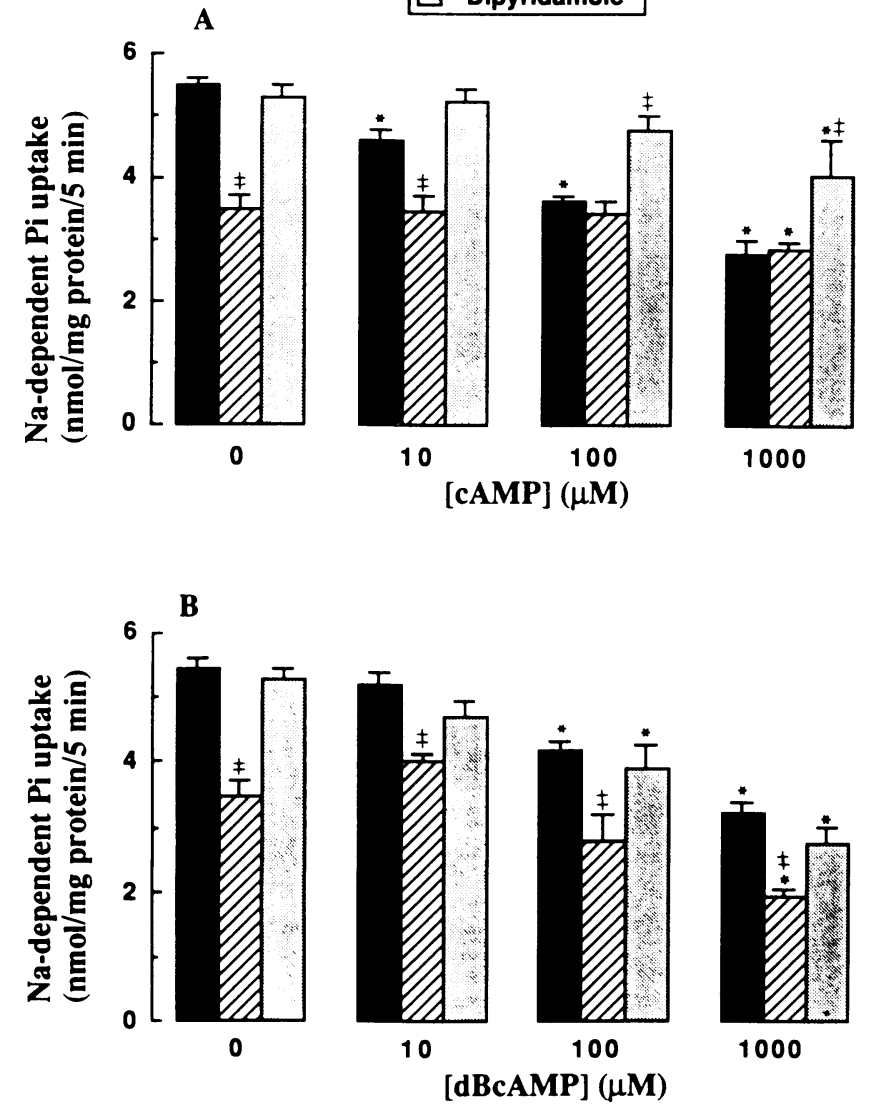

Figure 9. Effect of dipyridamole and probenecid on cAMP- and dBcAMP-induced inhibition of Na-dependent Pi uptake by OK cells. $\mathrm{OK}$ cells were incubated during $3 \mathrm{~h}$ with increasing concentrations of cAMP $(A)$ or $\mathrm{dBcAMP}(B)$ in the absence (black columns) or in the presence of probenecid ( $1 \mathrm{mM}$, hatched columns) or dipyridamole ( $20 \mu \mathrm{M}$, gray columns) before $\mathrm{Pi}$ uptake $(0.5 \mu \mathrm{Ci} / \mathrm{ml}, 0.1 \mathrm{mM}, 5$ $\min )$. Results are expressed as means $\pm \mathrm{SE}$ of four different $(n=4)$ experiments in which duplicates were obtained. *Significantly different from homologous value without cAMP or $\mathrm{dBcAMP}, P<0.01$;

${ }^{\dagger}$ significantly different from homologous value without dipyridamole or probenecid, $P<0.01$.

had any effect on Na-dependent uptake of L-Ala, D-Asp, and MGP. Adenosine was also ineffective to modulate these uptakes.

Effect of dipyridamole on Pi excretion in vivo. From in vitro studies on OK cells, it appeared that extracellular cAMP inhibited Pi transport through prior stepwise degradation of the cyclic nucleotide into adenosine followed by adenosine uptake. We tested the involvement of this pathway in vivo by evaluating the effect of dipyridamole infusion, intended to blunt adenosine uptake, on phosphaturia induced by cAMP infusion. As previously reported, infusion of CAMP to APTX rats, at a rate documented to raise plasma cAMP concentration between 1 and $2 \mu \mathrm{M}(8)$, increased FE Pi from $0.05 \%$ to $14.5 \%$. When dipyridamole was infused together with cAMP, FE Pi raised to only $1.0 \%$ (Fig. 11, left panel). Glomerular filtration rate was not different in the absence $(1.03 \pm 0.12 \mathrm{ml} / \mathrm{min}$ per $100 \mathrm{~g}$ of body $\mathrm{wt})$ or in the presence of dipyridamole $(0.93 \pm 0.18 \mathrm{ml} /$
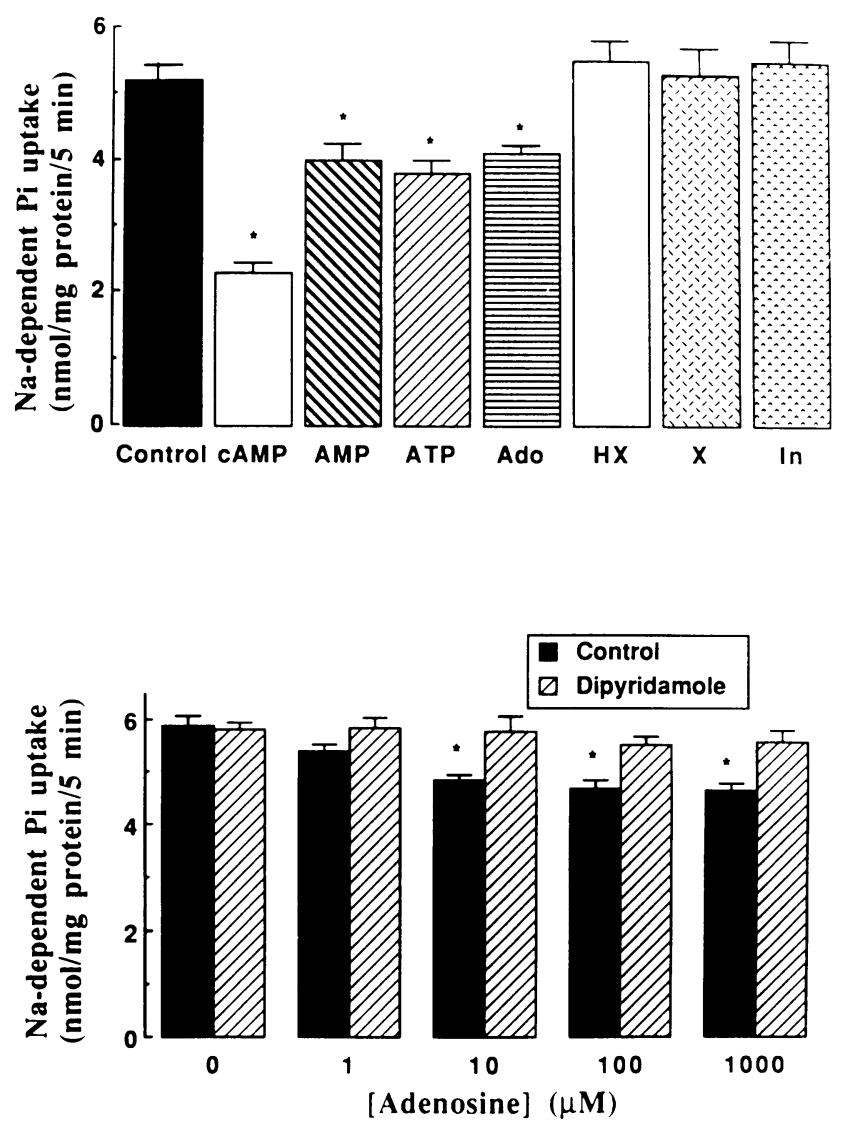

Figure 10. Effect of nucleosides and nucleotides on Na-dependent Pi uptake by OK cells. (A) OK cells were incubated with cAMP, AMP. ATP, adenosine $(A d o)$, hypoxanthine $(H X)$, xanthine $(X)$, or inosine $(I n)$, each of them at $1 \mathrm{mM}$, during $3 \mathrm{~h}$ before Pi uptake. $(B)$ OK cells were incubated with increasing concentrations of adenosine in the absence (black columns) or in the presence (hatched columns) of dipyridamole $(20 \mu \mathrm{M})$, during $3 \mathrm{~h}$ prior to Pi uptake $(0.5 \mu \mathrm{Ci} / \mathrm{ml}$, $0.1 \mathrm{mM}, 5 \mathrm{~min})$. Results are expressed as means \pm SE of four different $(n=4)$ experiments in which duplicates were obtained. *Significantly different from control value, $P<0.01$.

min per $100 \mathrm{~g}$ of body wt, NS). In contrast with the effect of dipyridamole on cAMP-induced phosphaturia, induction of phosphaturia by infusion of the permeant, phosphodiesteraseresistant analog dBcAMP was unchanged by dipyridamole (Fig. 11, right panel).

We next turned to the question of whether nephrogenous cAMP was instrumental in the overall phosphaturic effect of PTH. To answer this question, two sets of experiments were performed. In the first one, PTH-infused APTX rats received dipyridamole or its vehicle. As shown in Fig. 12 (left panel) dipyridamole decreased significantly $\mathrm{Pi}$ excretion. In the second set of experiments, intact rats were infused with dipyridamole. This drug decreased significantly Pi excretion to an extent similar to that observed in PTH-infused APTX rats. (Fig. 12, right panel). Again, glomerular filtration rate was unaffected by dipyridamole infusion ( $1.28 \pm 0.10 \mathrm{vs} .1 .12 \pm 0.15 \mathrm{ml} /$ min per $100 \mathrm{~g}$ of body wt, NS). 
Table III. Effect of Dipyridamole, Probenecid, and RO 20-1724 on PTH-induced Inhibition of Na-dependent Pi Uptake by $\mathrm{OK}$ Cells

\begin{tabular}{|c|c|c|c|c|c|}
\hline \multirow[b]{2}{*}{ [PTH] } & \multirow[b]{2}{*}{ Control } & \multirow[b]{2}{*}{$\begin{array}{l}\text { Dipyridamole } \\
\qquad(20 \mu \mathrm{M})\end{array}$} & \multirow[b]{2}{*}{$\begin{array}{l}\text { Probenecid } \\
\text { (1 mM) }\end{array}$} & \multicolumn{2}{|c|}{ RO 20-1724 } \\
\hline & & & & 10 & 100 \\
\hline$n M$ & \multicolumn{5}{|c|}{ nmol/mg protein per $5 \mathrm{~min}$} \\
\hline 0 & $5.0 \pm 0.21$ & $4.4 \pm 0.17$ & $4.5 \pm 0.21$ & $3.7 \pm 0.10$ & $3.0 \pm 0.12$ \\
\hline 0.1 & $4.1 \pm 0.14$ & $3.4 \pm 0.08$ & $3.6 \pm 0.07$ & $3.1 \pm 0.08$ & $2.4 \pm 0.10$ \\
\hline 1 & $3.1 \pm 0.04$ & $2.9 \pm 0.11$ & $3.0 \pm 0.13$ & $2.3 \pm 0.08$ & $2.1 \pm 0.06$ \\
\hline 10 & $2.5 \pm 0.03$ & $2.3 \pm 0.07$ & $2.4 \pm 0.10$ & $2.0 \pm 0.10$ & $1.7 \pm 0.07$ \\
\hline
\end{tabular}

OK cells were incubated during $3 \mathrm{~h}$ in the absence or presence of bPTH (1-34) and one of the agents at the indicated concentration before Pi uptake $(0.1 \mathrm{mM})$. Results represent means \pm SE of three different experiments $(n=3)$ in which duplicates were obtained. PTH, at any concentration tested, inhibited significantly $\mathrm{Pi}$ uptake in all experimental conditions $(P<0.01)$. The magnitude of inhibition was not significantly different whether dipyridamole, probenecid, or RO 20-1724 was present or absent.

\section{Discussion}

In the present study, we have demonstrated that: $(a)$ in OK cells, extracellular cAMP was metabolized into adenosine before uptake; $(b)$ in these cells, metabolism of extracellular cAMP into adenosine was a prerequisite to its inhibitory effect on $\mathrm{Pi}$ transport; and $(c)$ in vivo, this pathway was involved in the phosphaturic effect of exogenous CAMP and of exogenous or endogenous PTH.

Metabolism of extracellular cAMP precedes uptake. That metabolism of cAMP was a prerequisite to uptake was evidenced by the following: ( $a$ ) pharmacological inhibition of phosphodiesterases, either by RO 20-1724 (24) or, to a lesser extent, by probenecid (26), decreased radioactivity accumulation in cells incubated in the presence of labeled cAMP; $(b)$ inhibition of ecto- 5 '-nucleotidase by $\alpha, \beta$-methyleneadenosinediphosphate (26) or of adenosine uptake by dipyridamole (14, 17, and Fig. 6) decreased dramatically uptake of labeled cAMP, which strongly suggests that 5'-AMP was further converted into adenosine and that the nucleoside was the uptaken metabolite. This view is supported by the observation that un-
Table IV. Effect of Extracellular CAMP and of Agents That Increase Intracellular cAMP on Na-coupled Uptake of L-Ala, D-Asp, and MGP in OK Cells

\begin{tabular}{lccc}
\hline & \multicolumn{3}{c}{ Na-dependent uptake } \\
\cline { 2 - 4 } & L-Ala & D-Asp & MGP \\
\hline & \multicolumn{3}{c}{ nmol/mg protein per 5 min } \\
Control & $6.0 \pm 0.54$ & $4.8 \pm 0.03$ & $0.36 \pm 0.03$ \\
PTH $(10 \mathrm{nM})$ & $5.4 \pm 0.09$ & $5.4 \pm 0.14$ & $0.36 \pm 0.01$ \\
CAMP $(1 \mathrm{mM})$ & $5.7 \pm 0.35$ & $5.3 \pm 0.06$ & $0.33 \pm 0.02$ \\
Cholera toxin $(10 \mu \mathrm{g} / \mathrm{ml})$ & $5.1 \pm 0.35$ & $4.8 \pm 0.08$ & $0.31 \pm 0.09$ \\
Forskolin $(10 \mu \mathrm{M})$ & $5.5 \pm 0.14$ & $5.3 \pm 0.35$ & $0.34 \pm 0.09$ \\
RO 20-1724 $(50 \mu \mathrm{M})$ & $5.6 \pm 0.39$ & $5.7 \pm 0.45$ & $0.39 \pm 0.02$ \\
Adenosine $(1 \mathrm{mM})$ & $5.8 \pm 0.65$ & $5.2 \pm 0.19$ & $0.38 \pm 0.09$
\end{tabular}

OK cells were incubated during $3 \mathrm{~h}$ in the presence of one of the agents at the indicated concentration before uptake of L-alanine $(0.1$ $\mathrm{mM})$, D-aspartate $(0.1 \mathrm{mM})$, or (MGP $(0.1 \mathrm{mM})$. Results represent means \pm SE of three different experiments $(n=3)$ in which duplicates were obtained.

labeled adenosine or adenine nucleotides competed with cAMP (Fig. 2). That OK cells, which express many features of proximal tubular cells (27-29), were able to convert extracellular cAMP into AMP and adenosine on the one hand, and could synthesize ATP and, ultimately, cAMP from uptaken adenosine on the other hand (Fig. 4) is in line with previous reports on renal brush border membranes and proximal tubules: rat renal brush-border membranes were reported to express the activity of ecto-enzymes, including phosphodiesterases (30) and 5'-nucleotidase (31) responsible for stepwise hydrolysis of adenine nucleotides (32). Several lines of evidence support the view that intracellularly accumulated $\left[{ }^{3} \mathrm{H}\right]$ cAMP resulted from intracellular processing of uptaken adenosine: (a) appearance of $\left[{ }^{3} \mathrm{H}\right]$ adenosine in the cell preceeded that of $\left[{ }^{3} \mathrm{H}\right]$ cAMP (Fig. 4$) ;(b)$ blocking adenosine uptake prevented $\left[{ }^{3} \mathrm{H}\right]$ cAMP accumulation. Similar results were obtained in suspensions of rabbit proximal tubules which were shown to catabolize extracellular cAMP prior to uptake $(13,25)$. Species differences in enzymatic equipment account for the fact that the chemical form of accumulated radioactivity differed in rat or rabbit proximal tubules (33). Adenosine uptake, which has

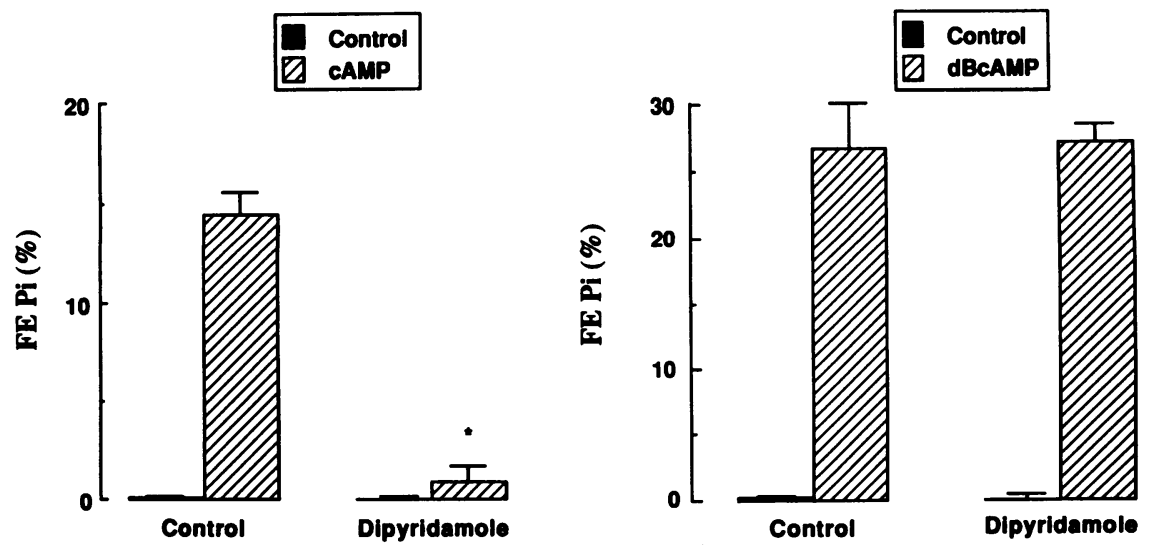

Figure 11. Effect of exogenous cAMP or $\mathrm{dBcAMP}$ and of dipyridamole on Pi excretion in rats. Left panel: Effect of cAMP infusion on fractional excretion of Pi (FE Pi) in APTX rats. In three rats (left columns), cAMP was infused alone. In three other rats (right columns), cAMP was infused concomitantly with dipyridamole. *Significantly different from homologous value without dipyridamole, $P<$ 0.01. Right panel: Effect of dBcAMP infusion on FE Pi in APTX rats. In three rats (left columns), cAMP was infused alone. In three other rats (right columns), cAMP was infused concomitantly with dipyridamole. 
APTX rats infused with PTH

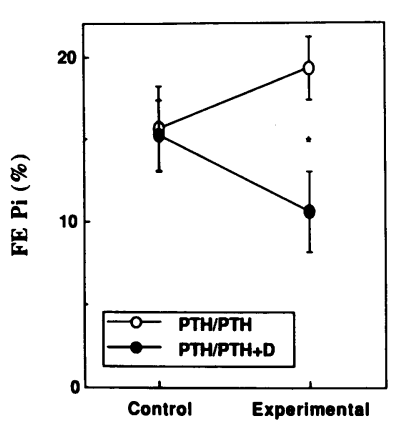

Intact rats

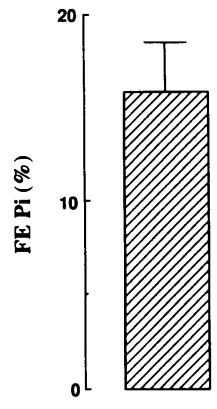

Control

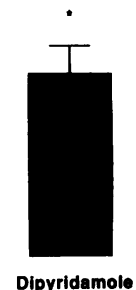

Dipyridamole

Figure 12. Effect of dipyridamole infusion on Pi excretion in PTHinfused APTX rats and in intact rats. Left panel: In five rats, fractional excretion of $\mathrm{Pi}(F E P i)$ was measured during infusion of PTH alone ( $\circ$; PTH / PTH). In three other rats, FE Pi was measured during infusion of PTH followed by infusion of PTH and dipyridamole in combination $(\bullet$; PTH/PTH+D). *Significantly different from homologous value without dipyridamole, $P<0.01$. Right panel: Fractional excretion of $\mathrm{Pi}$ was measured in four rats before (black column) and during ( hatched column) dipyridamole infusion. *Significantly different from control value without dipyridamole, $P<0.01$.

been extensively characterized in renal brush border membranes (14-16), is known to occur through two distinct transport systems, one of them being $\mathrm{Na}$ dependent $(15,16)$. These transport systems are highly efficient inasmuch as they allowed extracellular adenosine to play an important role in proximal tubules by providing precursors for ATP regeneration after anoxia (18). In OK cells, adenosine uptake was mainly $\mathrm{Na}$ independent (Fig. 6), and both $\mathrm{Na}$-dependent and $\mathrm{Na}$-independent components were sensitive to dipyridamole which almost abolished uptake. Sensitivity of adenosine transport systems to dipyridamole was reported to depend upon cell type or animal species. In rat renal brush-border membranes, this sensitivity varied from one study to another $(14,16)$. As suggested by Franco et al. (16), these discrepancies may be accounted for by the existence of different conformations of the adenosine transporter which are not equally sensitive to dipyridamole and by the fact that the equilibrium between these forms can depend upon the way of preparing membrane vesicles. It is noteworthy that, among the two transport systems involved in radioactivity uptake in OK cells incubated with labeled cAMP (Fig. 3), the high-affinity one had a $K_{\mathrm{m}}$ value close to that of adenosine uptake (Fig. 7), a feature consistent with the key role of the adenosine transporter in accumulation of a cAMP metabolite.

Mechanism of extracellular cAMP-induced inhibition of $P i$ transport. That the effect of CAMP on Pi uptake in OK cells was mediated by adenosine uptake was suggested by the following: (a) inhibition of phosphodiesterases by RO 20-1724 or by probenecid blunted, to a large extent, the effect of cAMP. Intrinsic inhibitory effect of both drugs on Pi uptake (Table II and Fig. 9) resulted likely from a decrease of both degradation and efflux of intracellular cAMP (34). It should be pointed out that the inhibitory effects of $100 \mu \mathrm{M}$ RO 20-1724 and of $1 \mathrm{mM}$ extracellular cAMP were of similar magnitude ( Table II). This is an indication, although indirect, that, under basal conditions, both intracellular cAMP generation and degradation in OK cells were quite intense. In this situation, imbalance be-

tween production and breakdown, such as that induced by phosphodiesterase inhibition, affected dramatically cAMP-regulated Pi transport; $(b)$ evidence that the inhibitory effect of cAMP and adenosine was blunted by dipyridamole indicates that adenosine uptake, rather than binding of the nucleoside to putative membrane receptors, was a mandatory step in the cascade of events leading to decreased Pi transport. The absence of nonspecific interaction between cAMP and probenecid or dipyridamole was ascertained by the evidence that dBcAMP, a permeant, phosphodiesterase-resistant analogue of cAMP, was still active in the presence of probenecid or of dipyridamole, which indicates that these drugs did not prevent intracellular events involved in modulation of Pi transport to occur. Along the same line, dipyridamole did not affect the phosphaturic effect of $\mathrm{dBcAMP}$ in vivo (Fig. 11). It may appear surprising that, at high concentration, the inhibitory effect of adenosine was of smaller magnitude than that of cAMP (Fig. 10). This could be accounted for by the documented inhibitory effect of adenosine, at high concentration, on adenosine-kinase which phosphorylates adenosine into AMP within the cell (18), leading ultimately to ATP formation.

Uptake of adenosine issued from metabolism of extracellular cAMP may not have represented the unique way by which high concentrations of cAMP affected Pi uptake. Indeed, at millimolar concentrations, the effect of cAMP was only partially reversed by dipyridamole (Fig. 9). This suggests that, besides the adenosine pathway, cAMP might enter cells in intact form through a low-affinity transport system, possibly similar to that involved in cAMP efflux in several cell types (34). Indeed, Ullrich et al. (12) reported that cAMP could enter proximal tubular cells at their basal pole through a pathway shared by PAH which competed with cAMP. The possibility that such a transport system was responsible for entry and effect of extracellular cAMP in our model is unlikely for the following: (a) Ullrich et al. reported that the affinity of the involved transport system for cAMP ( $1.5 \mathrm{mM})$ was far lower than that for dBcAMP, cGMP, or PAH. These findings are strikingly different from our own results in OK cells in which dBcAMP, cGMP, and PAH were less effective than unlabeled cAMP to decrease radioactivity accumulation in cells incubated with $\left[{ }^{3} \mathrm{H}\right]$ cAMP ( Table I); $(b)$ while PAH transport was inhibited by hypoxanthine but not by adenosine, AMP, ADP, and ATP (12), the pattern of inhibition of radioactivity accumulation in our model was just the opposite (Fig. 2); (c) finally, neither hypoxanthine nor PAH had any effect on cAMPinduced inhibition of $\mathrm{Pi}$ uptake. Altogether, these results strongly argue against a predominant, if any, entry of cAMP in intact form in the cells, at least for the concentrations used. Alternatively, cAMP might bind to brush-border membranes (35) and could therefore stimulate an ecto-protein kinase as evidenced in other cells (36). These possibilities, however, are unlikely to play a prominent role in vivo inasmuch as cAMP concentration in the proximal tubular fluid would not exceed $10 \mu \mathrm{M}$ in cAMP-infused rats (8). Luminal degradation of cAMP into adenosine followed by adenosine uptake was the most likely mechanism of cAMP-induced phosphaturia in that it was abolished by dipyridamole. It is noteworthy that infusion rate of dipyridamole was chosen in order to prevent any fall of glomerular filtration rate resulting from adenosine-induced vasoconstriction (37) which, in turn, would have been the consequence of an increase availability of adenosine for binding to 
glomerular receptors (38). In these conditions, decreased Pi excretion was univocally the reflect of enhanced tubular reabsorption.

As regards the intracellular steps involved in the biological effects of extracellular cAMP beyond adenosine uptake, evidence that de novo ATP synthesis occurred (Fig. 4) is in line with the results obtained by Mandel et al. who demonstrated that, in proximal tubules exposed to anoxia, restoration of ATP stores during reoxygenation was dramatically improved when adenosine or adenine nucleotides were present in the extracellular medium (18). That the part of cellular ATP which serves as substrate for adenylate cyclase may be substantial was evidenced by Kather in adipocytes (39). In these cells, stimulation of adenylate cyclase by catecholamines decreased ATP content by $33 \%$ after $1 \mathrm{~h} \mathrm{(39)}$. It is therefore reasonable to propose that, given the very rapid ATP turnover in proximal cells (18), additional ATP synthesis from adenosine might have resulted in additional synthesis of cAMP. As discussed above, both adenylate cyclase and phosphodiesterase activities in proximal cells are high, as evidenced by the effect of imbalance between these two phenomenons during phosphodiesterase inhibition (Fig. 8). Adenosine, which was also reported to inhibit phosphodiesterases $(24,40)$, might have, by this way as well, contributed to inhibit Pi transport. Concerning postcAMP events, they included protein kinase $A$ activation since the effect of extracellular cAMP was blunted in the presence of $\mathrm{H} 8$, a protein kinase A inhibitor (not shown).

Involvement of luminal $C A M P$ in the overall phosphaturic effect of PTH. At this point, the question arises of whether extracellular cAMP may play a role in the modulation of renal Pi transport under physiological conditions. Addition of cAMP to the tubular fluid, which occurs under the influence of PTH in the proximal convoluted tubule (7), combines with water reabsorption to increase cAMP concentration to nearly 150 $\mathrm{nM}$ at the end of proximal tubule accessible to micropuncture (7), that is, at the beginning of the proximal straight tubule, a major site of PTH action on Pi transport (1). We therefore hypothesized that, if cAMP degradation in the lumen was instrumental to modulate Pi transport, dipyridamole, which was shown to block luminal but not basolateral adenosine uptake (14), should decrease Pi excretion. This was indeed the case in both PTH-infused APTX rats and in intact animals (Fig. 12), indicating that part of the phosphaturic effect of PTH is, in fact, exerted by extracellular cAMP added to the lumen under the influence of the hormone.

In conclusion, the present study has evidenced that extracellular cAMP inhibition of renal phosphate transport occurred most likely through stepwise hydrolysis of the cyclic nucleotide into adenosine by the brush border membranes, followed by luminal adenosine uptake. Luminal cAMP, added to the tubular fluid under the influence of PTH, accounts for one third of the overall phosphaturic effect of the hormone. These results bring new insights in the mechanism of PTH modulation of renal Pi transport and may open therapeutic perspectives in hypophosphatemic genetic diseases.

\section{Acknowledgments}

The authors dedicate this work to the memory of Dr. H. Kuntziger.

We are indebted to Dr. F. Roch-Ramel (Lausanne, Switzerland) for the generous gift of OK cells.
This work was supported by grants from INSERM, CNRS, Université Paris 7, Faculté Xavier-Bichat, Fondation pour la Recherche Médicale, 'and Laboratoire de Recherches Physiologiques.

\section{References}

1. Amiel, C., D. Chabardès, and C. Bailly. 1982. Effects of parathyroid hormone on the kidney: sites and mechanisms of action. Adv. Nephrol. 11:147-189.

2. Gmaj, P., and H. Murer. 1986. Cellular mechanisms of inorganic phosphate transport in kidney. Physiol. Rev. 66:36-70.

3. Morel, F., and A. Doucet. 1986. Hormonal control of kidney function at the cell level. Physiol. Rev. 66:377-468.

4. Dunlat, R., and K. Hruska. 1990. PTH receptor coupling to PLC is an alternate pathway of signal transduction in bone and kidney. Am. J. Physiol. 258:F223-F231.

5. Chase, L. R., and G. D. Aurbach. 1967. Parathyroid function and the renal excretion of 3'5'-adenylic acid. Proc. Natl. Acad. Sci. USA. 58:518-525.

6. Broadus, A. E., J. E. Mahaffey, F. C. Bartter, and R. M. Neer. 1977. Nephrogenous cyclic adenosine monophosphate as a parathyroid function test. $J$. Clin. Invest. 60:771-783.

7. Küntziger, H., H. Cailla, C. Amiel, and M. Delaage. 1981. Influence of parathyroid status of rats on renal tubular handling of adenosine 3'5'-monophosphate: a micropuncture study. J. Cyclic Nucleotide Res. 7:313-319.

8. Kuntziger, H., C. Amiel, N. Roinel, and F. Morel. 1974. Effects of parathyroidectomy and cyclic AMP on renal transport of phosphate, calcium, and magnesium. Am. J. Physiol. 227:905-911.

9. Amiel, C., H. Kuntziger, S. Couette, C. Coureau, and N. Bergounioux. 1976. Evidence for a parathyroid hormone-independent calcium modulation of phosphate transport along the nephron. J. Clin. Invest. 57:256-263.

10. Coulson, R. 1976. Metabolism and excretion of exogenous adenosine 3':5'-monophosphate and guanosine 3':5'-monophosphate. J. Biol. Chem. 251:4958-4967.

11. Podevin, R. A., and E. F. Boumendil-Podevin. 1975. Inhibition by cyclic AMP and dibutyryl cyclic AMP of transport of organic acids in kidney cortex. Biochim. Biophys. Acta. 375:106-114.

12. Ullrich, K. J., G. Rumrich, F. Papavassilious, S. Klöss, and G. Fritzsch. 1991. Contraluminal p-aminohippurate transport in the proximal tubule of the rat kidney. VII. Specificity: cyclic nucleotides, eicosanoids. Pflügers Arch. Eur. J. Physiol. 418:360-370.

13. Boumendil-Podevin, E. F., and R. A. Podevin. 1977. Transport and metabolism of adenosine $3^{\prime}: 5^{\prime}$-monophosphate and $\mathrm{N}^{6}, \mathrm{O}^{2 \prime}$-dibutyryl adenosine 3':5'-monophosphate by isolated renal tubules. J. Biol. Chem. 252:6675-6681.

14. Trimble, M. E., and R. Coulson. 1984. Adenosine transport in perfused rat kidney and renal cortical membrane vesicles. Am. J. Physiol. 246:F794-F803.

15. Le Hir, M., and U. C. Dubach. 1985. Concentrative transport of purine nucleosides in brush border vesicles of the rat kidney. Eur. J. Clin. Invest. 15:121 127.

16. Franco, R., J. J. Centelles, and R. K. H. Kinne. 1990. Further characterization of adenosine transport in renal brush-border membranes. Biochim. Biophys. Acta. 1024:241-248.

17. Plagemann, P. G. W., and J. M. Aran. 1990. Characterization of $\mathrm{Na}^{+}$-dependent, active nucleoside transport in rat and mouse peritoneal macrophages, a mouse macrophage cell line and normal rat kidney cells. Biochim. Biophys. Acta. 1028:289-298.

18. Mandel, L. J., T. Takano, S. P. Soltoff, and S. Murdaugh. 1988. Mechanisms whereby exogenous adenine nucleotides improve rabbit renal proximal function during and after anoxia. J. Clin. Invest. 81:1255-1264.

19. Friedlander, G., and C. Amiel. 1989. Protein kinase C activation has dissimilar effects on sodium-coupled uptakes in renal proximal tubular cells in primary culture. J. Biol. Chem. 264:3935-3941.

20. Friedlander, G., C. Le Grimellec, J. Sraer, and C. Amiel. 1990. 12-HETE modulates Na-coupled uptakes in proximal tubular cells: role of diacylglycerol kinase inhibition. Am. J. Physiol. 259:F816-F822.

21. Bradford, M. M. 1976. A rapid and sensitive method for the quantitation of microgram quantities of protein utilising the principle of protein-dye binding. Anal. Biochem. 72:248-254.

22. Snedecor, G. W., and W. G. Cochran. 1972. Statistical Methods. $6^{\text {th }}$ edition. Iowa State University Press, Ames, IA. 593 pp.

23. Amer, M. S., and W. E. Kreighbaum. 1975. Cyclic nucleotide phosphodiesterases: properties, activators, inhibitors, structure-activity relationships, and possible role in drug development. J. PharmaSci. 64:1-37.

24. Beavo, J. A. 1988. Multiple isozymes of cyclic nucleotide phosphodiesterase. Adv. Second Messenger Phosphoprotein Res. 22:1-38.

25. Podevin, R. A., E. F. Boumendil-Podevin, J. Bujoli-Roche, and C. Priol. 1980. Effects of probenecid on transport and metabolism of cyclic AMP by isolated rabbit renal tubules. Biochim. Biophys. Acta. 629:135-142. 
26. Kather, H. 1990. Pathways of purine metabolism in human adipocytes. $J$. Biol. Chem. 265:96-102.

27. Malmström, K., and H. Murer. 1986. Parathyroid hormone inhibits phosphate transport in OK cells but not in LLC-PK 1 and JTC-12.P3 cells. Am. J. Physiol. 251:C23-C31.

28. Caverzasio, J., R. Rizzoli, and J.-P. Bonjour. 1986. Sodium dependent phosphate transport inhibited by parathyroid hormone and cyclic AMP stimulation in an opossum kidney cell line. J. Biol. Chem. 261:3233-3237.

29. Malström, K., G. Stange, and H. Murer. 1987. Identification of proximal tubular functions in the established kidney cell line, OK. Biochim. Biophys. Acta. 902:269-277.

30. Filburn, C. R., and B. Sacktor. 1976. Cyclic nucleotide phosphodiesterases of rabbit renal cortex. Arch. Biochem. Biophys. 174:249-261.

31. Le Hir, M., S. Angielski, and U. C. Dubach. 1985. Properties of an ecto-5'nucleotidase of the renal brush border. Renal Physiol. 8:321-327.

32. Culic, O., I. Sabolic, and T. Zanic-Grubisic. 1990. The stepwise hydrolysis of adenosine nucleotides by ectoenzymes of rat brush-border membranes. Biochim. Biophys. Acta. 1030:143-151.
33. Weinberg, J. M. 1991. The cell biology of ischemic renal injury. Kidney Int. 39:476-500.

34. Strewler, G. J. 1984. Release of cAMP from a renal epithelial cell line. Am. J. Physiol. 246:C224-C230.

35. Insel, P., R. Balakir, and B. Sacktor. 1975. The binding of cyclic AMP to renal brush border membranes. J. Cyclic Nucleotide Res. 1:107-122.

36. Kubler, D., W. Pyerin, O. Bill, A. Hotz, J. Sonka, and V. Kinsel. 1989. Evidence for ecto-protein kinase activity that phosphorylates kemptide in a cyclic-dependent manner. J. Biol. Chem. 264:14549-14555.

37. Osswald, H., W. S. Spielman, and F. G. Knox. 1978. Mechanism of adenosine-mediated decrease in glomerular filtration rate in dogs. Circ. Res. 43:465-469.

38. Abboud, H. E., and T. P. Dousa. 1983. Action of adenosine on cyclic 3',5' nucleotides in glomeruli. Am. J. Physiol. 244:F633-F638.

39. Kather, H. 1990. Beta-adrenergic stimulation of adenine nucleotide catabolism and purine release in human adipocytes. J. Clin. Invest. 85:106-114.

40. Bonnafous, J.-C., J. Dornand, and J.-C. Mani. 1979. Adenosine-induced cyclic AMP increase in pig lymphocytes is not related to adenylate cyclase stimulation. Biochim. Biophys. Acta. 587:180-191. 